\title{
Overexpression of $\gamma$-glutamylcysteine synthetase gene from Caragana korshinskii decreases stomatal density and enhances drought tolerance
}

\author{
Baiyan Lư ${ }^{1,2,3}$, Xinjuan Luo ${ }^{2}$, Chunmei Gong ${ }^{1}$ and Juan Bai ${ }^{{ }^{*}}$
}

\begin{abstract}
Background: Gamma-glutamylcysteine synthetase $(\gamma-E C S)$ is a rate-limiting enzyme in glutathione biosynthesis and plays a key role in plant stress responses. In this study, the endogenous expression of the Caragana korshinskii $y$-ECS (Cky-ECS) gene was induced by PEG 6000-mediated drought stress in the leaves of C. korshinskii. and the Cky-ECS overexpressing transgenic Arabidopsis thaliana plants was constructed using the C. korshinskii. isolated $\gamma$-ECS.

Results: Compared with the wildtype, the Cky-ECS overexpressing plants enhanced the $\gamma$-ECS activity, reduced the stomatal density and aperture sizes; they also had higher relative water content, lower water loss, and lower malondialdehyde content. At the same time, the mRNA expression of stomatal development-related gene EPF1 was increased and FAMA and STOMAGEN were decreased. Besides, the expression of auxin-relative signaling genes AXR3 and ARF5 were upregulated.

Conclusions: These changes suggest that transgenic Arabidopsis improved drought tolerance, and Cky-ECS may act as a negative regulator in stomatal development by regulating the mRNA expression of EPF1 and STOMAGEN through auxin signaling.
\end{abstract}

Keywords: Drought stress, Auxin signaling, Gamma-glutamylcysteine synthetase, Stomatal development

\section{Background}

Water deficiency is one of the main reasons for poor plant performance and crop yields worldwide [1]. The global losses in crop yields due to drought totaled $\sim \$ 30$ billion in the past decade. Drought causes a wide range of changes including reduced leaf sizes, loss of root hairs, low water-use efficiency, and reduced photosynthesis [24]. Plants adopt multiple inherent strategies to (i) escape (acceleration of the reproductive phase before stress could impact its survival), (ii) avoid (increase internal

\footnotetext{
*Correspondence: baijuan@nwsuaf.edu.cn

${ }^{1}$ College of Horticulture, Northwest A\&F University, Yangling 712100,

Shaanxi, China

Full list of author information is available at the end of the article
}

water content), and (iii) tolerate drought (sustain growth with low internal water content during drought period) [5]. For example, redox homeostasis, root-associated microbiome, and transcription factors are all involved in plant resistance to drought. Oxidative damages can occur due to excessive reactive oxygen species (ROS) accumulated during water shortage [6]. ROS are the results of the partial reduction of atmospheric $\mathrm{O}_{2}$ and are metabolic products in all cells. Under physiological conditions, ROS function as intracellular messengers in redox signaling and many cellular processes, and there is a frail balance between ROS production and breakdown. Under stress, slight enhancement in ROS production is sensed by the plant as an alarm and triggers defense responses; while 
excessive accumulation of ROS and unrestricted oxidation will cause damages to DNA, proteins, and lipids, and ultimately cause cell death $[7,8]$.

The antioxidant glutathione (GSH) alleviates ROS damages, mainly through the redox signaling pathways [9-11]. The biosynthesis of GSH is tightly regulated by the rate-limiting enzyme gamma-glutamylcysteine synthetase ( $\gamma$-ECS) [12]. In Arabidopsis, overexpression of $\gamma$-ECS (from S. cerevisiae strain S288C) led to a higher tolerance to heavy metals and the accumulation of arsenic and cadmium ions [13]. Over-expression of bacterial $\gamma$-ECS in poplar (Populus tremula $\times P$. alba) and tobacco affected the photosynthesis and improved adaptability under mild drought and metal exposure [14-16]. In transgenic Arabidopsis overexpressing $\gamma$-ECS without seed vernalization, the level of flowering repressor FLOWERING LOCUS increased, suggesting that floral transition requires redox changes in GSH [17].

Stomata are vital to the drought tolerance of plants. Stomatal closure and the consequent limitation on $\mathrm{CO}_{2}$ fixation are ways of ROS accumulation under drought conditions [8]. As a gateway for water transpiration and photosynthesis $\mathrm{CO}_{2}$ exchange, stomata open and close pores according to the turgidity of a pair of guard cells $[18,19]$. The development of stomata undergoes several stages. In Arabidopsis thaliana, stomatal lineage initiates from asymmetric divisions of meristemoid mother cells to generate meristemoids, which reiterate several asymmetric divisions to produce neighboring nonstomatal cells, before finally producing the guard mother cells (GMC). GMC undergoes a single symmetric division to produce a set of paired guard cells to form mature stomata [20]. These divisions require the basic helixloop-helix (bHLH) transcription factors SPEECHLESS $(\mathrm{SPCH}), \mathrm{MUTE}$, and FAMA [21, 22]. The activities of $\mathrm{SPCH}, \mathrm{MUTE}$, and FAMA are regulated by an intrinsic signaling pathway including the secreted peptides, EPIDERMAL PATTERNING FACTORS (EPFs), receptorlike kinases ERECTA (ER) family, receptor-like protein TOO MANY MOUTHS (TMM) and MAPK cascades [20, 23, 24]. EPF1 and EPF2 expressed in the epidermis are negative regulators of stomatal development in Arabidopsis. Their activities depend on the TMM and ER family receptor kinases. They are genetically upstream of the genes for TMM, ER family, and the MAPKs cascades [25, 26]. EPF2 is primarily perceived by ER and the co-receptor TMM to inhibit stomatal development [27]. TMM is a negative regulator of stomatal formation in cotyledons and leaves [28, 29]. Transgenic Arabidopsis, tomato, and rice overexpressing ER showed improved heat tolerance and increased biomass in the greenhouse and field tests [30]. STOMAGEN, which is expressed in mesophyll and is a member of the EPFL family of proteins (EPF-LIKE9)
[31], migrates to the epidermis where it is proposed to positively regulate stomatal density and stomatal index by competitively inhibiting TMM-mediated signaling [32]. Auxin signaling is a fundamental part of many plant growth processes and stress responses and operates through auxin/indole-3-acetic acid (Aux/IAA) protein degradation and the transmission of the signal via auxin response factors (ARFs) [33-35]. ARF5 directly binds to the STOMAGEN promoter to inhibit its expression, suggesting auxin negatively regulates stomatal development through ARF5 repression of the mobile peptide gene STOMAGEN in the mesophyll [36]. It has been shown that guard cells accumulate more GSH than other epidermal cells [37]. However, the precise function of GSH remains uncharacterized.

C. korshinskii is a leguminous shrub with strong tolerance to drought, cold, salt, and other biotic and abiotic stresses, and is widely distributed in arid and semiarid areas in the wilderness of Northwestern China [38]. Here, we isolated $\gamma$-ECS from C. korshinskii and characterized its role in mediating drought stress tolerance. The results suggest that $C k \gamma-E C S$ may participate in the negative regulation of auxin-mediate signaling to regulate stomatal development.

\section{Results \\ The stomatal density of C. korshinskii leaves decreased with drought}

The lowest stomata density was measured in leaves from Dongsheng, the driest site of the sampling sites. Under natural conditions, the stomatal density of $C$. korshinskii leaves decreased with intensified drought stress $(P<0.05$, Fig. 1).

\section{Expression of stomatal development-related genes was changed after PEG 6000 treatment in C. korshinskii} The relative expressions of stomatal developmentrelated genes (CKFAMA, CkSTOMAGEN, CKARF5, and CkAXR3) were evaluated by qRT-PCR (Fig. 2). Under polyethylene glycol-6000 (PEG 6000) induced drought to C. korshinskii seeds, the expressions of CKFAMA and CkSTOMAGEN were decreased (Fig. 2a, d); the expression of CKARF5 was increased slightly without a statistical difference (Fig. 2c), and the expression of CkAXR3 was increased (Fig. 2b). The results suggested that auxin signaling may be involved in the stomatal development of C. korshinskii. Under drought. The expression of $C k \gamma$ $E C S$ and the $\gamma$-ECS activities also increased significantly with drought stresses (2.17-fold for 5\% PEG and 4.6-fold for $10 \%$ PEG, Fig. 2e, f). These findings suggest that $C k \gamma$ $E C S$ is related to stomata development by auxin signaling to adapt to drought in C. korshinskii. 

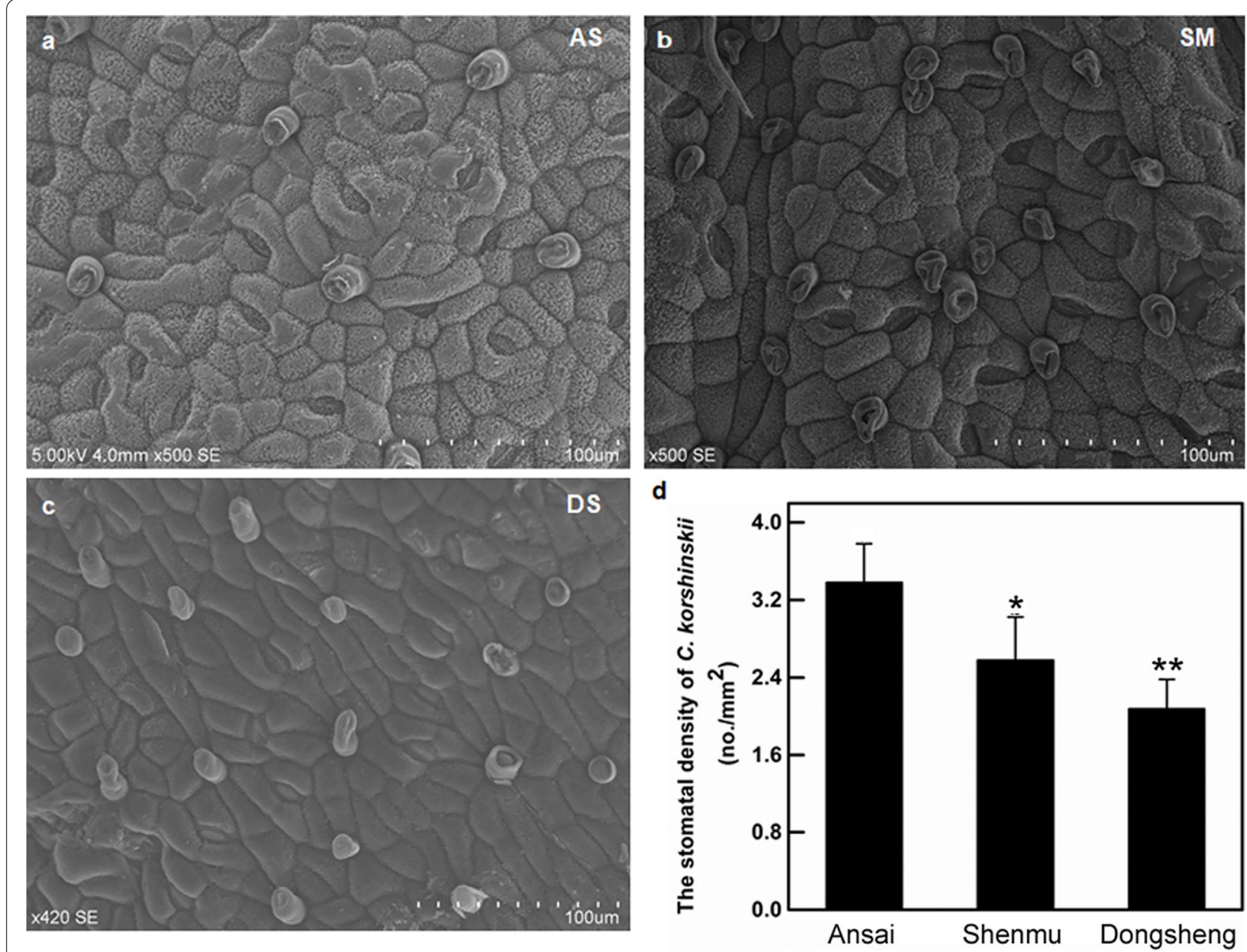

Fig. 1 The stomatal density of Caragana korshinskii with different precipitation areas from Loess Plateau in China. Scanning electron micrographs of C. korshinskii leaves in Ansai, Shenmu, Dongsheng (a-c). The stomatal density of the C. korshinskii leaf with three sites (d). The data were shown above as means $\pm \operatorname{SD}(n \geq 3) .{ }^{*}$ and ${ }^{* *}$ indicate that compared with Ansai, $P<0.05$ and $P<0.01$

\section{Isolated Cky-ECS genes share a high identity with other Leguminosae plant $\gamma$-ECS}

The $C k \gamma$-ECS gene was isolated from C. korshinskii using reverse-transcription PCR (RT-PCR), and the template was taken from the transcriptome data of C. korshinskii (Figs. S1 and S2). The Cky-ECS has an open reading frame of 1527 nucleotides, encoding 508 amino acids with an estimated molecular weight of $57.59 \mathrm{kDa}$ and a calculated pI of 6.85. Sequence alignments indicated that the putative protein shared higher sequence identity with its homologous sequences, including (Fig. 3) Cicer arietinum (XP_004503722.1, 91\%), Medicago truncatula (XP_003630512.1,90\%), Cajanus cajan (XP_020216402.1, 88\%), Pisum sativum (AAF22137.1, 88\%), Lotus japonicus (AAO45821.1, 87\%), Glycine max (XP_003525397.1, 87\%), Phaseolus vulgaris (XP_007160058.1, 86\%), Vigna angularis (XP_017441981.1, 86\%), Glycine soja
(KHN16824.1, 86\%), Phaseolus vulgaris (AAF22136.1, 86\%), Arachis duranensis (XP_015955550.1, 85\%), Arachis ipaensis (XP_016189524.1, 85\%), Vigna radiata (NP_001304203.1, 85\%) (Fig. 3a). The putative protein contained the HELICc, ELK, FN2, and UBA domains, which were highly conserved amongy-ECS proteins (Fig. 3a). A phylogenetic analysis was performed to evaluate the evolutionary relationshipwith other species (Fig. 3b), and the results showed that Cky-ECS had a high degree of identity with the $\gamma$-ECS from other Leguminosae plants such as Medicago truncatula, Phaseolus vulgaris, Vigna angularis, Vigna radiata (Fig. 3b).

\section{Generation and identification of Cky-ECS transgenic Arabidopsis lines}

In order to verify the function of $C k \gamma$-ECS, we generated transgenic Arabidopsis overexpressing the Cky-ECS 

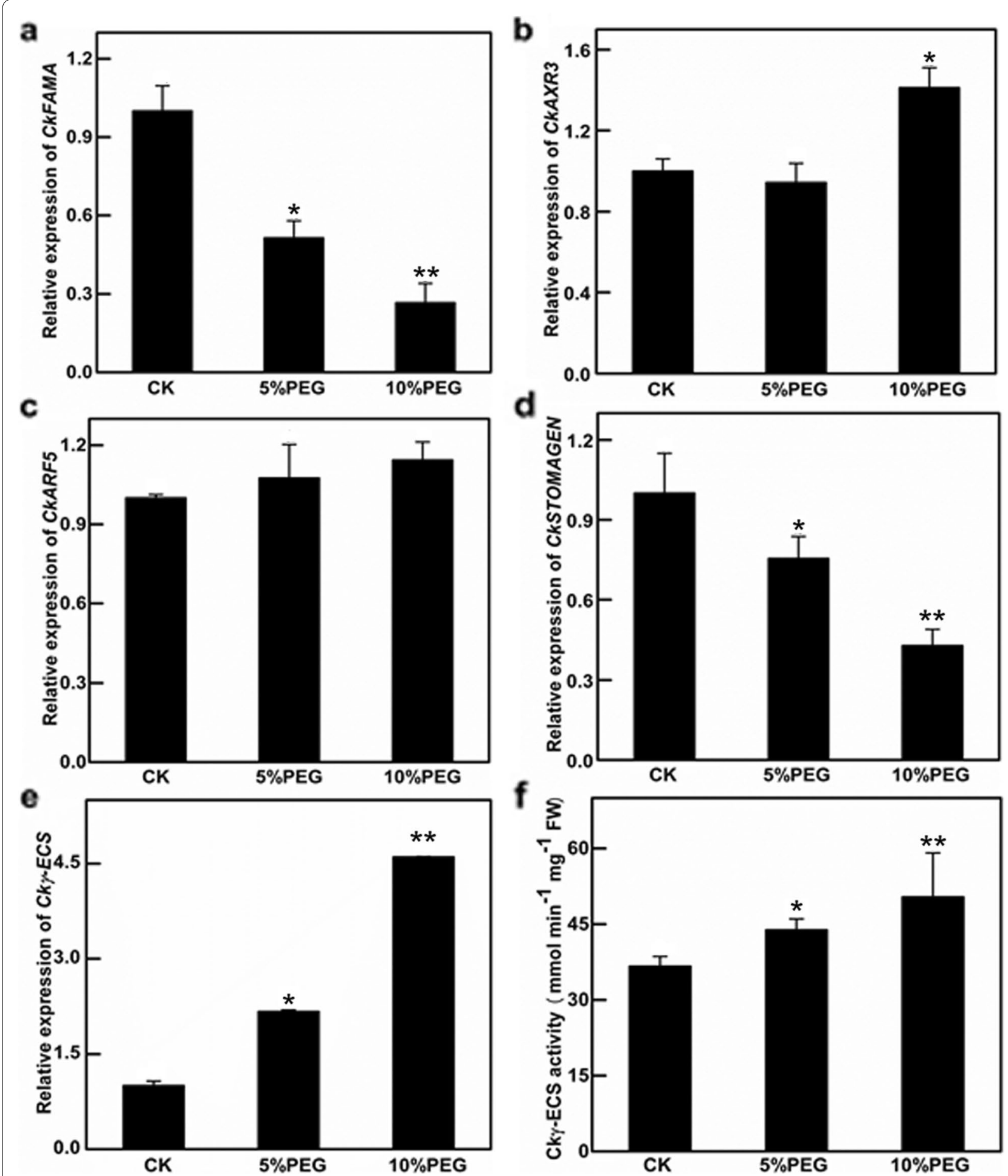

Fig. 2 Relative genes expression and $\gamma$-ECS activity in Caragana korshinskii under different drought treatments. Relative genes expression of C. korshinskii (control, 5 and 10\% PEG), including CKFAMA, CKAXR3, CKARF5, CKSTOMAGEN, and Cky-ECS (a-e).y-ECS activity in C. korshinskii under different drought treatments (control, 5, 10 and 15\% PEG 6000) (f). The data represented mean \pm SD $(n=3), C K=$ control. $^{*}$ and ${ }^{* *}$ indicate that compared with controls, $P<0.05$ and $P<0.01$ 


\section{a}

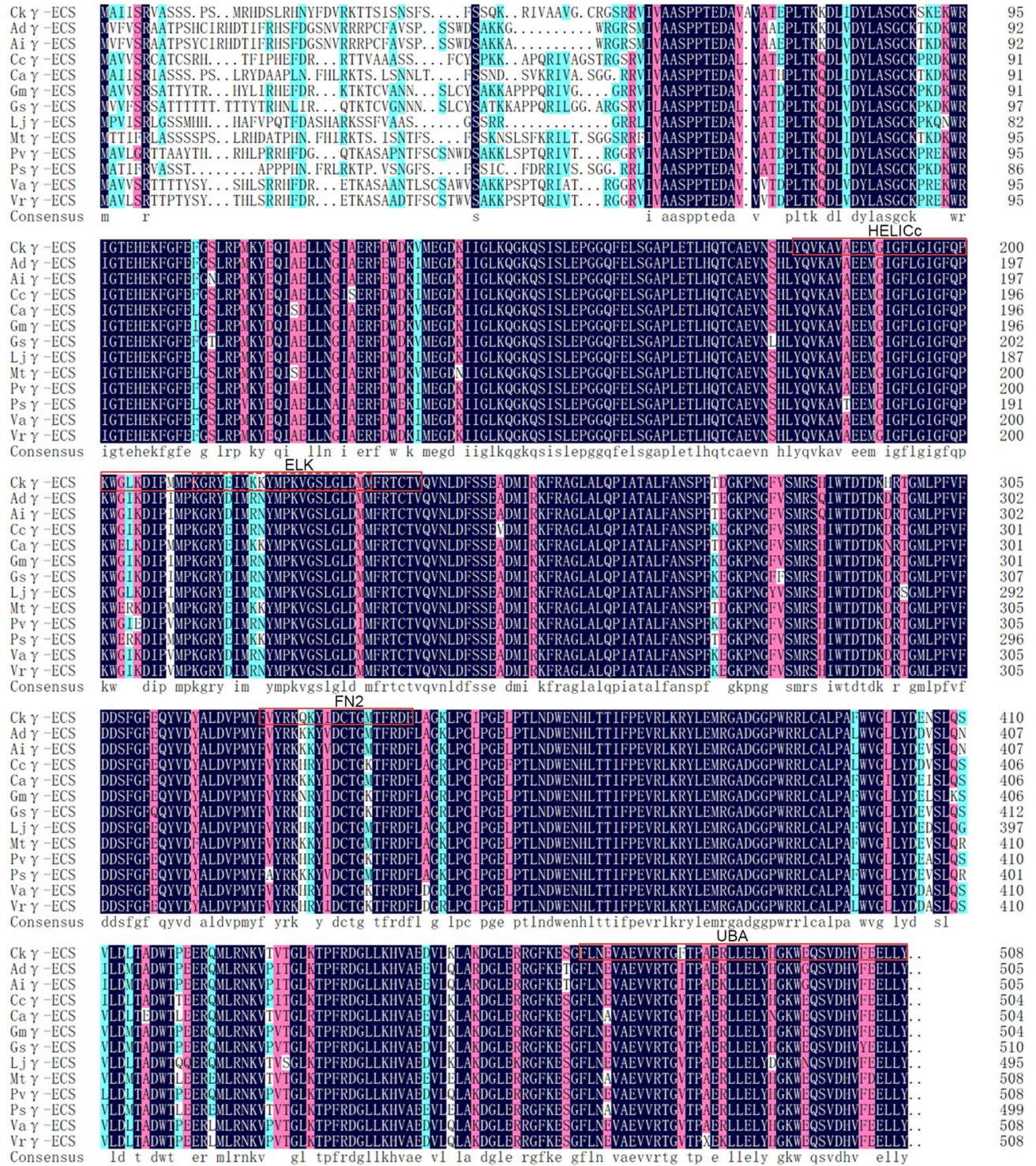

b

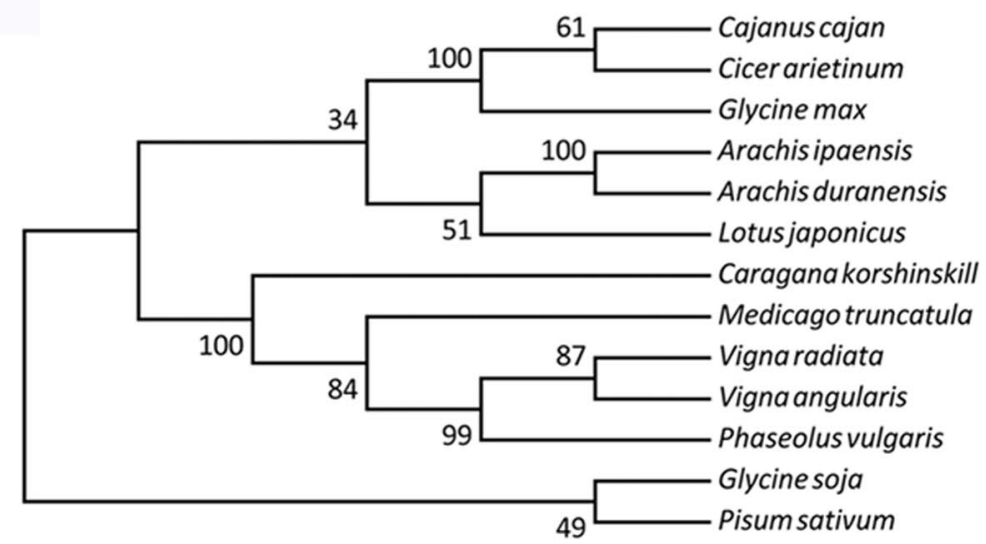

Fig. 3 Sequence and phylogenetic analyses of Cky-ECS. Multiple alignments among the amino acid sequences of the putative protein of the Cky-ECS and its known homologs (a). Phylogenetic relationship among the putative Cky-ECS protein and other species (b) 
cDNA without the termination under the control of the CaMV35S promoter and GFP fusion protein (Fig. S3a). Plants survived on the kanamycin selection medium and homozygous transgenic lines were obtained (Fig. S3b). After subsequent screening in T1 and T2 plant lines, homozygous T3 lines without resistance segregation on the selective medium were obtained and identified by the reverse transcription PCR amplification of the $C k \gamma-E C S$ gene using specific primers (Fig. S3c). The western blotting analysis showed that the Cky-ECS was expressed in the transgenic lines with an anti-GFP (Fig. S3d). T3 transgenic lines were used for further physiological studies.

\section{Stomatal density and aperture sizes decreased in $C k \gamma$-ECS overexpressing Arabidopsis}

The Cky-ECS overexpressing Arabidopsis leaves were longer and narrower (Fig. S4), and their stomatal density and leaf aperture sizes were significantly reduced compared with those of WT plants (26.04 and $26.66 \%$ respectively, $P<0.05$, Fig. 4). Overexpression of $C k \gamma$-ECS led to a reduction in Arabidopsis stomatal density. The phenotypes of transgenic lines and WT plants under drought stress are shown in Fig. 5. The RWC of WT plants was significantly reduced (Fig. 5c). However, plants overexpressing Cky$E C S$ exhibited slower water loss in detached rosette leaves (Fig. 5d). Compared with WT, the MDA content of transgenic plants was significantly reduced (Fig. 5e). Compared with WT plants, the Cky-ECS transgenic Arabidopsis had a longer main root length withholding water for 7 days, and a shorter plant height at 60 days (Fig. 6). Together, the data indicate that overexpression of $C k \gamma$-ECS in transgenic Arabidopsis can significantly improve drought tolerance.

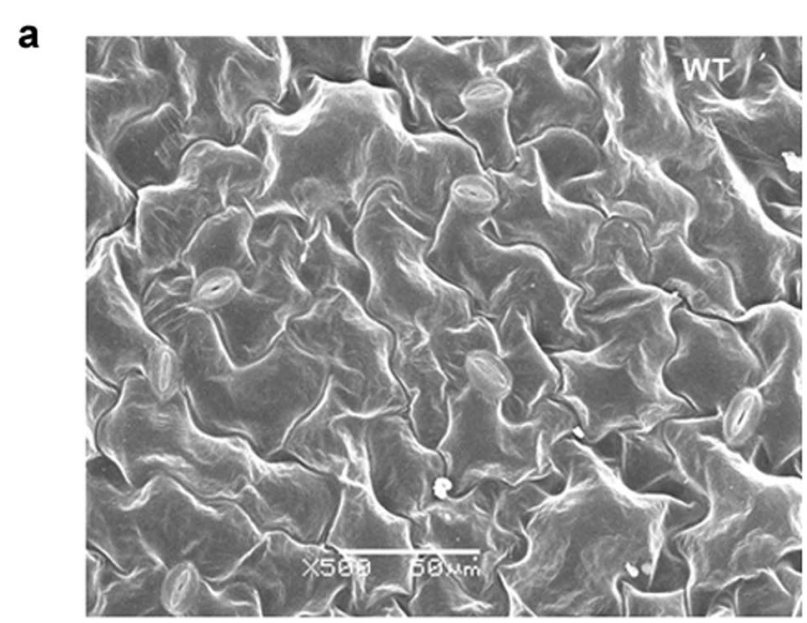

b

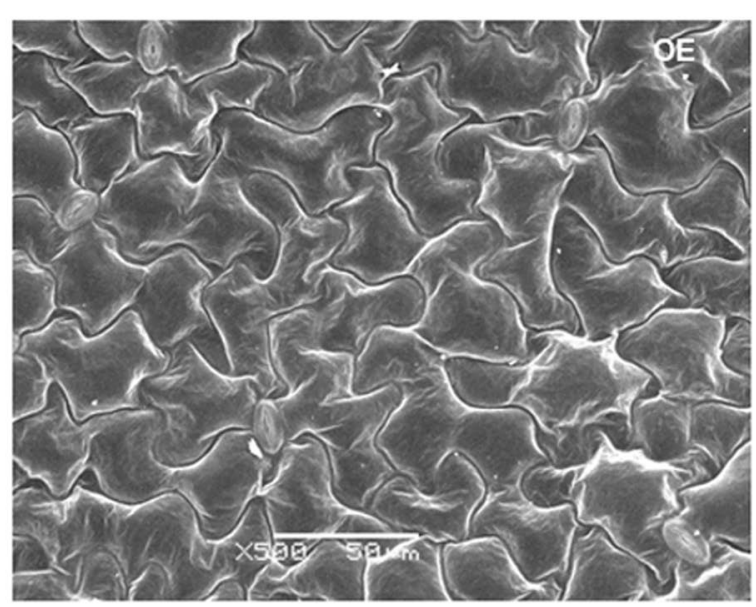

C

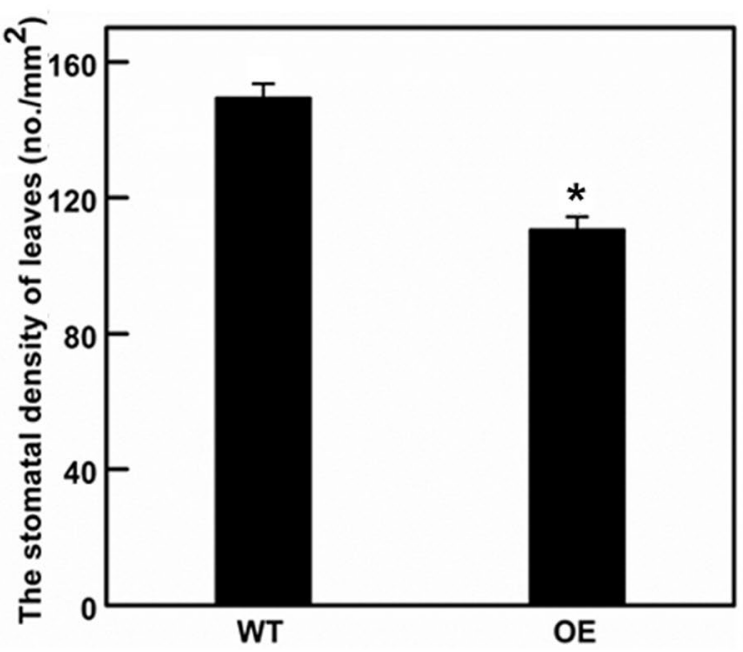

d

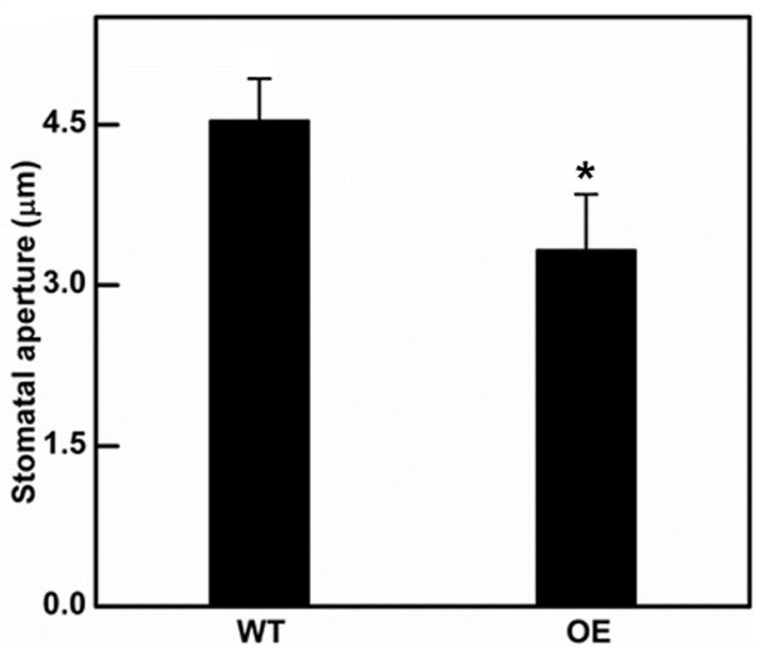

Fig. 4 The effects of stomatal development on overexpressing plants. Scanning electron micrographs of Arabidopsis leaves (a, b 500X). Stomatal density and stomatal aperture of the Arabidopsis leaf between overexpression (OE) and wild type (WT) (c, d). * indicates $P<0.05$ 


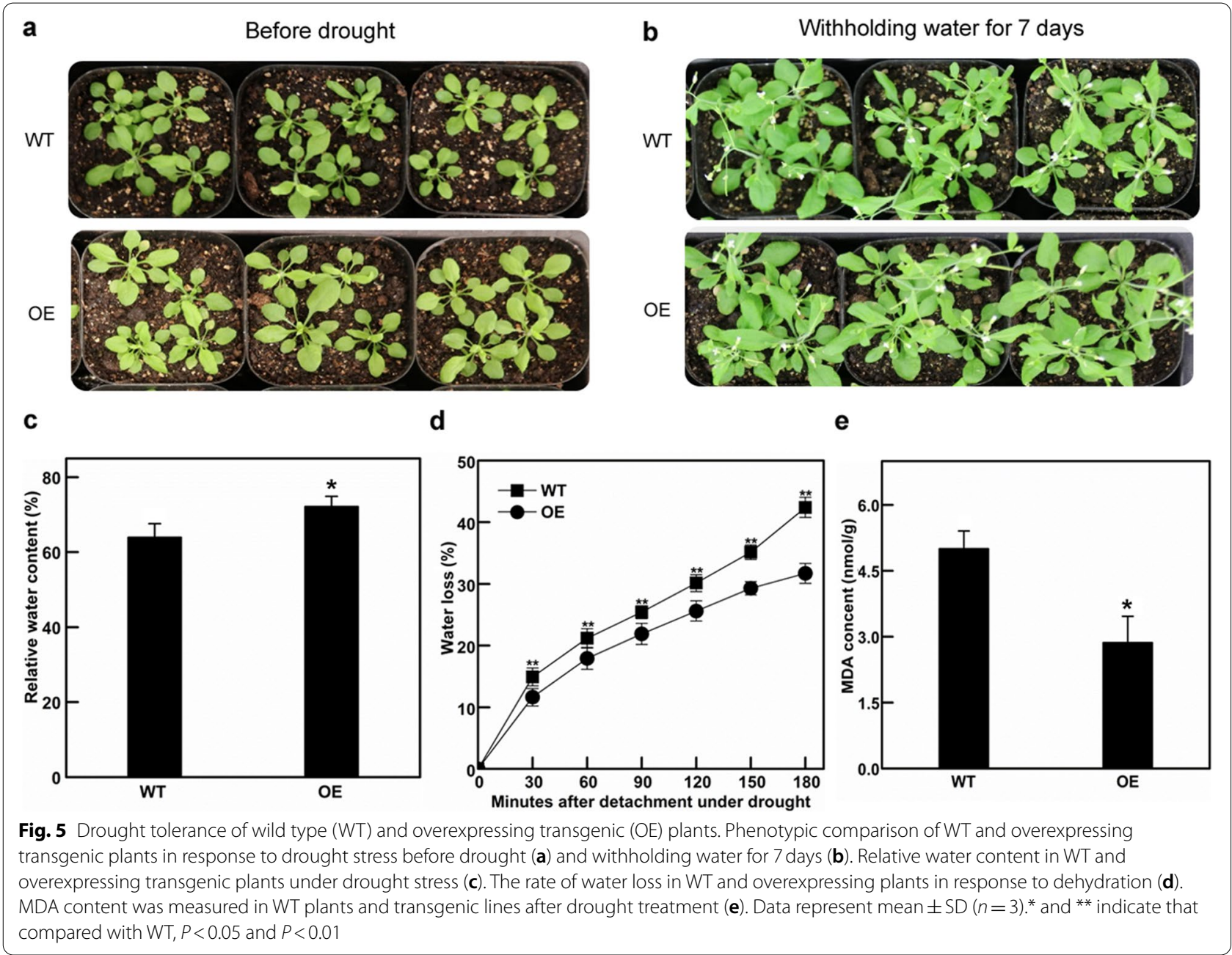

\section{Relative expression of stomatal development-related} genes was changed in $\mathrm{C} \boldsymbol{k} \boldsymbol{\gamma}$-ECS overexpressing Arabidopsis The levels of AtFAMA and AtSTOMAGEN mRNA in the transgenic plants were significantly lower than those in the WT (Fig. 7). The expressions of AtAXR3, AtARF5 and $A t E P F 1$ in the transgenic plants increased significantly. There was no significant difference in the expression of Aty-ECS between WT and transgenic plants (Fig. 7b), suggesting that overexpression $C k \gamma$-ECS did not affect the expression of endogenous genes. However, $\gamma$-ECS activity in transgenic Arabidopsis was significantly increased (Fig. 7b).

\section{Discussion}

We examined the effects of a GSH rate-limiting enzyme $\gamma$-ECS on the plant drought tolerance both in C. korshinskii. and in $\mathrm{Ck} \gamma$-ECS transgenic Arabidopsis lines, and revealed that $C k \gamma$-ECS improved plant drought tolerance and the possible mechanism was stomatal development inhibition through regulating the auxin signaling (changed EPF1 and STOMAGEN expressions). The $\gamma$-ECS gene isolated from $C$. korshinskii and the putative proteins shared a high identity with those from other Leguminosae species.

Stomata play crucial roles in plant responses to various abiotic stresses. Under the natural environment of the three sampling sites in the Loess Plateau, the stomatal density of $C$. korshinskii decreased with increased drought stress. Under drought treatment, the expressions of stomatal development positive regulators $C k F A M A$ and CkSTOMAGEN in C. korshinskii were inhibited, and the expresson of auxin-response gene $C k A X R 3$ was enhanced (CKARF5 was not enhanced). Furthermore, the expression of $\mathrm{Ck} \gamma$-ECS and activity of $\gamma$-ECS were significantly increased under drought treatment. Previous study show that drought stress positively affect auxin-response genes (such as Aux/IAA, ARFs, Gretchen Hagen3 (GH3), small auxin-up RNAs, and lateral organ boundaries (LBD)), to regulate plant growth and development [35, 39-41], which was consistent with our 
a

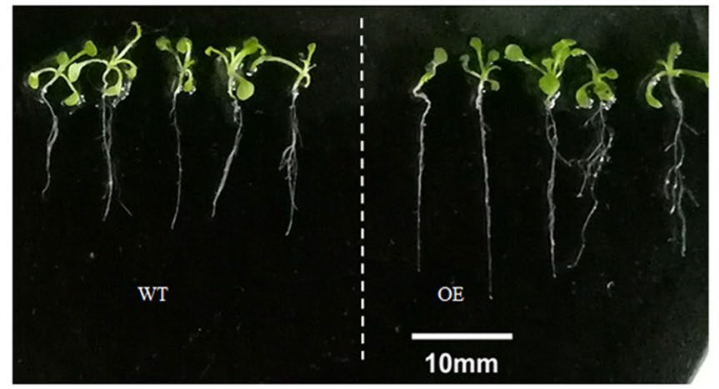

c

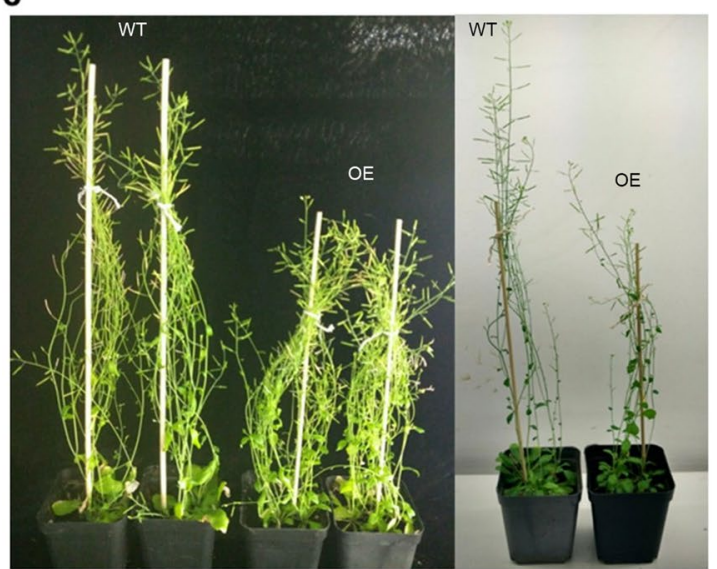

b
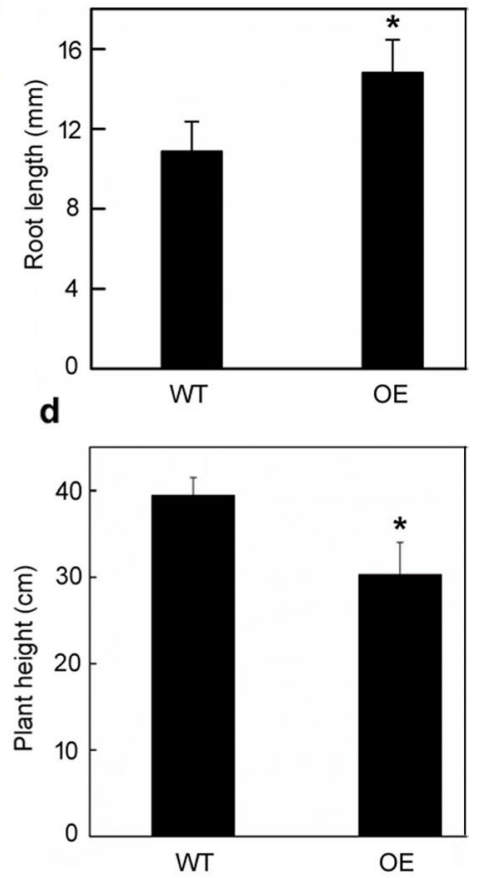

Fig. 6 Main root length ( $\mathrm{mm}, 7$ days) $(\mathbf{a}, \mathbf{b})$ and plant height ( $\mathrm{cm}, 60$ days) $(\mathbf{c}$, d) of Arabidopsis thaliana plants overexpressing Cky-ECS (OE) and wild type (WT) plants. * indicates $P<0.05$

observation. The results indicated that $C k \gamma-E C S$ may be related to the stomatal development in $C$. korshinskii. by ARFs to cope with drought.

In the $C k \gamma$-ECS overexpressing Arabidopsis thaliana, the stomatal density and leaf aperture size was significantly reduced. In Arabidopsis thaliana, STOMAGEN positively and EPF1 and EPF2 negatively regulate the leaf stomatal density, and they are perceived by a receptor complex composed of the receptor-like proteins TMM, ER, and ERL1/2 [42]. STOMAGEN positively regulates stomatal formation and $\mathrm{SPCH}$ protein levels, [42, 43] while EPF1 and EPF2 act antagonistically to STOMAGEN, they activate MAP kinase that phosphorylates and destabilizes the SPCH [42]. The effect of FAMA on epidermal stomatal density and frequency was consistent with that of STOMAGEN [44]. In this study, the expression of AtSTOMAGEN and AtFAMA significantly decreased while the expression of AtEPF1 was enhanced in transgenic lines (Fig. 7a), which explained the reduction in stomatal density.

Many stress tolerance mechanisms are related to hormone signaling, such as BR [45], ABA [19], and auxin [36]. The phytohormone auxin signaling is a fundamental part of plant growth processes and stress responses [46].
Auxin accumulation activates signaling pathways and inducts auxin-responsive genes, which are mediated by the Aux/IAA and ARFs protein families [33-35]. Another report showed that auxin inhibited stomatal development through auxin response factors. ARF5 directly binds to the STOMAGEN promoter to inhibit its expression and thereby suppresses the development of stomat a[36]. As shown in Fig. 7a, ARF5 and STOMAGEN mRNA levels were opposite in overexpressing $C k \gamma$-ECS plants. This result was consistent with a previous study in which the transgenic line with overexpression of the OsIAA6 gene improved tolerance to drought stress via the regulation of auxin biosynthesis genes [40]. In the present study, the expression of AtAXR3 (an auxin-inducible gene, same as IAA17 protein) is promoted, in a large part, which owes to the genetical position of AXR3 in upstream of the YDA MAP kinase cascade to regulate stomata formation in response to light and auxin signals [47]. There are some Aux/IAA members induced in different plants under drought. SbIAA8, SbIAA11, SbIAA 22 in leaves and $S b I A A 23$ in roots were significantly up-regulated exposed to drought conditions in Sorghum bicolor [39]. 15 (OsIAA1, 2, 4, 6, 7, 9, 13, 16, 18, 19, 20, 21, 22, 27, and 30 ) genes were induced by drought treatment in rice 

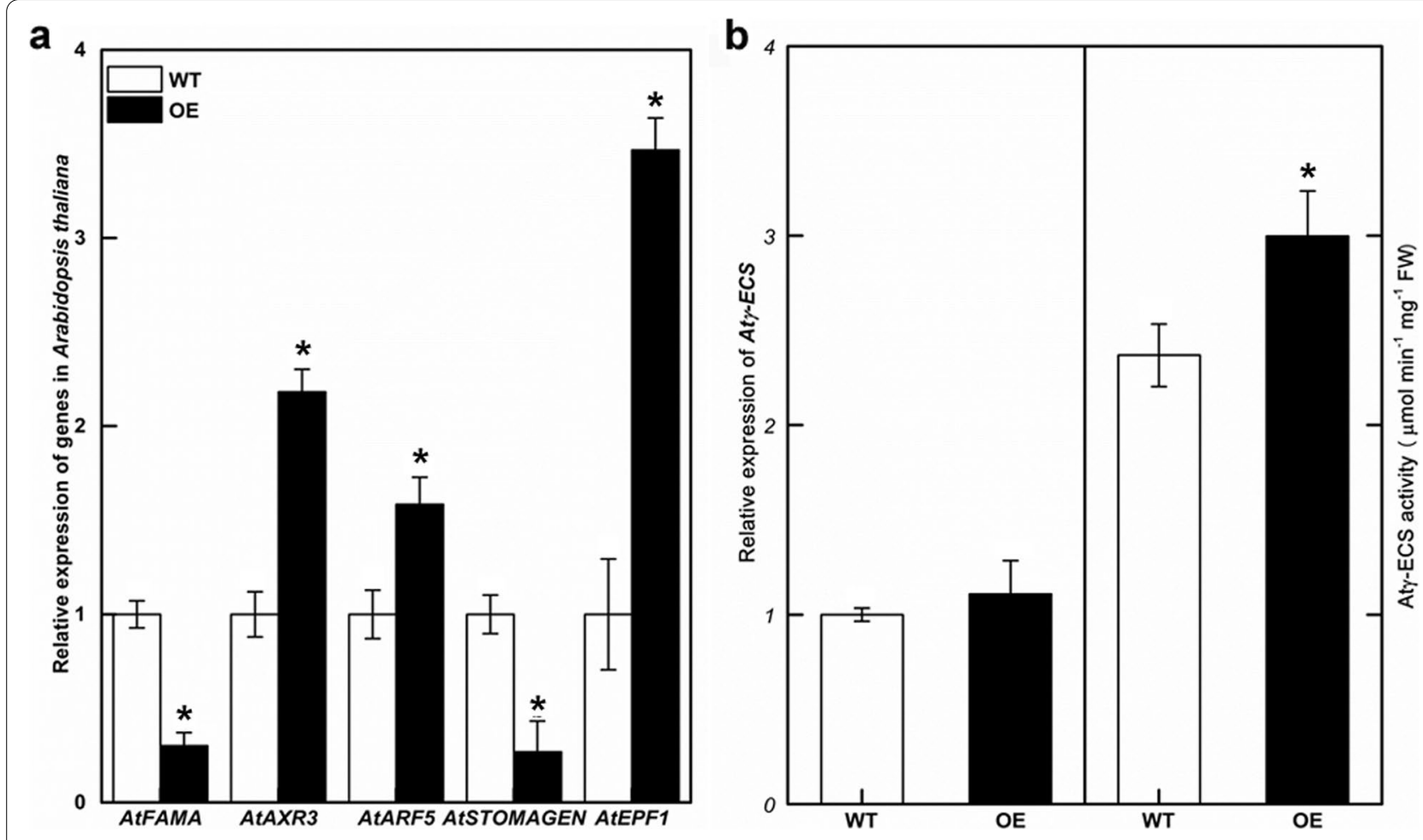

Fig. 7 Relative genes expression and $\gamma$-ECS activity in Arabidopsis thaliana. Relative genes expression of Arabidopsis thaliana with overexpression lines and wild type (WT) (a). $y$-ECS expression and $y$-ECS activity in overexpression lines and WT (b). The data represented mean \pm SD $(n=3)$, and * indicates $P<0.05$

[48]. Furthermore, $\gamma$-ECS activity in transgenic plants of overexpressing $C k \gamma-E C S$ was significantly increased (Fig. 7b), in line with the previous report [16]. Previous studies indicated that overexpression of the $\gamma$-ECS gene enhanced tolerance to drought in poplars [16]. These results suggested that $\gamma$ - ECS could regulate stomatal development by mediating the auxin signaling pathway.

Under drought stress, $C k \gamma$-ECS overexpressing plants grew better than wild-type plants (Fig. 5b), they had higher RWC, lower water loss, and lower MDA content (Fig. 5c-e). RWC and water loss are typical phenotypic and physiological parameters used to assess the water status of plants under drought stress $[49,50]$. MDA content in tissues can be used as a biomarker to estimate the degree of lipid peroxidation and tolerance to oxidative damage caused by dehydration stress [51]. These results indicated that overexpression of $C k y-E C S$ can enhance plant resistance and tolerance to drought stress.

\section{Conclusions}

We cloned and characterized the $C k \gamma$-ECS gene from C. korshinskii. The overexpression of Cky-ECS resulted in increased tolerance to drought stress in transgenic Arabidopsis lines. The function of $C k \gamma-E C S$ may be to negatively regulate stomatal development in response to drought by affecting the level of auxin-related genes. However, a detailed molecular mechanism by which $C k \gamma$-ECS regulates stomatal density to adapt to drought remains unclear and requires further study.

\section{Methods}

\section{Plant materials and growth conditions}

The three sampling sites selected for natural C. korshinskii seeds were Ansai, Shenmu, and Dongsheng (with the annual precipitation and relative humidity of $506.5 \mathrm{~mm}$, $60.8 \%$; $440.8 \mathrm{~mm}, 54 \%$; and $325.8 \mathrm{~mm}, 48.5 \%$; respectively; Data available online (http://data.cma.cn/data/cdcdetail/ dataCode/A.0029.0004.html) or in the provincial Statistical Yearbook published by the Statistics Bureau), along a precipitation gradient from south to north across the Loess Plateau in north-west China. The sampling procedures were carried out in accordance with the institute guidelines by professor Fang Xiangwen from Lanzhou University. Sampled C. korshinskii seeds were grown in sterile distilled water under $16 \mathrm{~h}$ of light at $25^{\circ} \mathrm{C}$ and $8 \mathrm{~h}$ of dark at $22^{\circ} \mathrm{C}$. The drought treatments included mock, $5 \%$ (w/v) PEG 6000, and 10\% PEG 6000. After 20 days of growth, plants were sampled and stored with different treatments at $-80^{\circ} \mathrm{C}$ for future tests. 
Seeds of Arabidopsis thaliana (Col-0) were produced in our lab in the Northwest A\&F University and maintained by Dr. Yang Yazhou. The wild-type Arabidopsis thaliana (WT, ecotype Col-0) and overexpressing (OE) plants were germinated under long-day conditions $(16 \mathrm{~h} / 8 \mathrm{~h}$, day/night cycles) at a controlled temperature $\left(20^{\circ} \mathrm{C}\right.$, day or night) and relative air humidity of $65 \%$. These plants were grown in plastic square pots $(6.8 \mathrm{~cm} \times 6.8 \mathrm{~cm} \times 7.8 \mathrm{~cm})$ filled with soil (Pindstrup Sphagnum Moss Peat, Ryomgaard, Denmark) in a growth chamber. After 4 weeks, shoots were collected and stored in liquid N2. Some Arabidopsis plants were grown in Petri dishes on half-strength Murashige and Skoog medium (1/2 MS medium, pH5.8) with $1 \%$ sucrose and $0.8 \%$ plant agar on $90 \mathrm{~mm}$ circular plates and stored for 3 days in cold and dark to synchronize germination. Then, the plates were placed in a plant growth chamber with 16 h day photoperiod and $20^{\circ} \mathrm{C}$. After 10 days the shoots were collected and stored in liquid $\mathrm{N}_{2}$. After growing the plants in the soil for 4 weeks under normal conditions, stress treatment was started. Then, drought was induced by withholding water to both the overexpression plants and wild-type plants (all 12 replicates of each group were analyzed).

\section{Stomatal density}

Leaf samples (width: $5-7 \mathrm{~mm}$ ) were fixed in $4 \%$ glutaraldehyde (Sigma, USA) at $4{ }^{\circ} \mathrm{C}$ overnight, and then washed four times with $0.1 \mathrm{M}$ phosphate buffer (PBS, pH6.8) for $10 \mathrm{~min}$. The samples were dehydrated with a series of ethanol mixtures (30\%, 50\%, 70\%, 80\%, and 90\% ethanol) for $15 \mathrm{~min}$, and then washed twice with $100 \%$ ethanol and isoamyl acetate for $30 \mathrm{~min}$, respectively. The stomatal density was observed by scanning electron microscopy (SEM6360LV). Image analysis was performed using Image (NIH, Bethesda, MD, USA). All experiments were carried out with three biological replicates and three technical experiments.

\section{RNA extraction and real-time qRT-PCR analysis}

Total genomic DNA was extracted from plant leaves using the DNA-quick Plant System (Tiangen, Beijing, China) according to the manufacturer's instructions. Total RNA was isolated from leaves using Quick RNA Isolation Kit (Huayueyang Biological Technologies, Beijing, China) according to the manufacturer's instructions. The pairs of primer specific for -ECS were in PCR analysis. The PCR program used was: $95^{\circ} \mathrm{C}$ for $5 \mathrm{~min}$; then 37 cycles of $94^{\circ} \mathrm{C}$ for $30 \mathrm{~s}, 58^{\circ} \mathrm{C}$ for $15 \mathrm{~s}$ and $72^{\circ} \mathrm{C}$ for $2 \mathrm{~min}$; with a final step at $72^{\circ} \mathrm{C}$ for $10 \mathrm{~min}$. The PCR process was performed with 1 unit of Phanta ${ }^{\mathrm{TM}} \mathrm{EVO}$ HS Super- Fidelity DNA Polymerase (Vazyme, Nanjing,
China), dNTP Mix (10 mM each), a pair of primers (10 $\mu \mathrm{M}$ each), $5 \times$ EVO Buffer (with $10 \mathrm{mM} \mathrm{MgCl}_{2}$ ), DNA template, and $\mathrm{dd}_{2} \mathrm{O}$ in a final volume of $50 \mu \mathrm{l}$. The PCR products were analyzed on $1 \%$ agarose gels stained with ethidium bromide (EB) and visualized using the Visible Imaging System (Bio-rad, USA). For RT-PCR analysis, $2 \mu \mathrm{g}$ of each total RNA sample was treated with the Fast Quant RT Kit (with gDNase) according to the manufacturer's instructions (Tiangen, Beijing, China).

Quantitative Real-time PCR used ABI StepOnePlus. The primers for the Actin7 gene of Arabidopsis and ubiquitin gene of $C$. korshinskii were used as an internal control. Each reaction contained $7.5 \mu \mathrm{l}$ of $2 \times$ ChamQ SYBR qPCR Master Mix (Vazyme, Nanjing, China), $1.5 \mu \mathrm{l}$ of diluted cDNA template, $200 \mathrm{nM}$ primers and $0.3 \mu \mathrm{l}$ $50 \times \mathrm{ROX}$ reference Dye, then $\mathrm{dd}_{2} \mathrm{O}$ was added up to $15 \mu \mathrm{l}$. The reaction procedures were as follows: denature at $95^{\circ} \mathrm{C}$ for $30 \mathrm{~s}$, followed by 40 cycles of $95^{\circ} \mathrm{C}$ for $10 \mathrm{~s}$, $60^{\circ} \mathrm{C}$ for $30 \mathrm{~s}$, melting curve by $95^{\circ} \mathrm{C}$ for $10 \mathrm{~s}, 60^{\circ} \mathrm{C}$ for $60 \mathrm{~s}, 95^{\circ} \mathrm{C}$ for $15 \mathrm{~s}$. The relative expression of the genes was calculated using the relative $2^{-\Delta \Delta C T}$ method. The primers used in this study are listed in Table 1.

\section{Isolation and sequence analysis of $C k \gamma$-ECS}

The primers for $C k \gamma$-ECS were designed based on the sequences of transcriptome data (Fig. S1). The PCR product was cloned into the pGEM-T Easy Vector System (Promega, USA) using PCR primers (Table 1). The products were inserted into the SacI/PstI-digested pCAMBIA2301 binary vector (modified). After that, the plasmids were introduced into Agrobacterium strain GV3101. The putative amino acid sequences were deduced using BioEdit and ExPASy (https://web.expasy. org/protparam/). The multiple protein alignment was performed using Clustal X software (version 2.0). DNAMAN (version 5.2.2) was used for sequence assembling and SMART (http://smart.embl-heidelberg.de/smart/set_ mode.cgi?NORMAL=1) was used for conserved domain analysis. The phylogenetic tree was constructed with the neighbor-joining (NJ) method for molecular evolutionary analysis using TreeView in MEGA (version 5.10).

\section{Construction of $C k \boldsymbol{y}$-ECS transgenic Arabidopsis plants}

The 35S: $C k \gamma$-ECS-GFP vector was introduced into Arabidopsis for overexpression studies. Arabidopsis transformation used the floral dip method [52]. After harvest, the $\mathrm{T} 1$ seeds were dried on allochroic silica gel at room temperature and germinated on $1 / 2 \mathrm{MS}$ medium containing $50 \mu \mathrm{g} \mathrm{ml}^{-1}$ carbenicillin to select transgenic seedlings. Seeds obtained from the primary transgenic lines were germinated on an antibiotic medium, and PCR analysis was performed on resistant plants. The surviving 
Table 1 Gene-specific primers used for cloning and qRT-PCR

\begin{tabular}{|c|c|c|}
\hline Gene & Forward primer (from $5^{\prime}$ to $3^{\prime}$ ) & Reverse primer (from $5^{\prime}$ to $3^{\prime}$ ) \\
\hline Cky-ECS(cloning) & ATGGCTATCATCTCCCGA & ATAAAGCAACCTCAAATA \\
\hline$C k \gamma-E C S$ & TGCGAGCTCATGGCTATCATCTCCCGA & CGGCTGCAGATAAAGCAATTCCTCAAATA \\
\hline$q C k \cup B$ & GACTTTGACCGGGAAGACCA & CACCACGAAGACGGAGCACA \\
\hline qCKFAMA & TGAACGTAGGAACCAGGCA & AACAAGAGGAAGAGACCAAGAAG \\
\hline qCKAXR3 & CTGGAAGATGTTTGTGGAATCA & AGGGACATTTACATCGTCATTACAC \\
\hline qCKARF5 & GTCAGTGTGCCTCGTCGTCTC & TGTCCTCCCCGTTAATCTTCA \\
\hline qCKSTOMAGEN & AATCCTCACAACCTCAAAGAGAACT & TGGGGTCATTTCCCTCCACAGG \\
\hline$q C k \gamma-E C S$ & AAGTTGGTTCTCTCGGGCT & CGGTGCTTATCAGTATCGGTC \\
\hline qAtActin7 & CACTACCGCAGAACGGGAAA & GCGATGGCTGGAACAGAACC \\
\hline qAtFAMA & CAGCAACATCAACTCTCTCCTTCC & TCTGGTCTGGTTCAACGCAA \\
\hline qAtAXR3 & CTCTTTTACCATGGGCAAACATGGA & AGGGAACATAGTCCCAGCTATTCA \\
\hline qAtARF5 & TAATGGGGAATGGAGGTTTG & GTGTAGAGTTCTCAGGTTTAGCAG \\
\hline qAtSTOMAGEN & TAGGGTCGACAGCACCAACTTGTAC & TCATTTCCTTCGACTGGAACTTGCT \\
\hline qAtERF1 & TTCTTCTCCTTGCCTTTTTCC & AACCTAGACCCAGCCACCTG \\
\hline$q A t y-E C S$ & CTGTTAAGAGGAGTAAGAGAGGGC & CCAGAGGCAAGATAGGCAATG \\
\hline
\end{tabular}

positive T1 plantlets were transferred to soil to harvest T2 seeds. T2 and T3 seeds were germinated as previously described. T3 seeds were harvested and used as the materials for all experiments in Arabidopsis.

\section{Detection of transgenic lines}

The transgenic lines were detected by PCR and Western blotting. A pair of $C k \gamma$-ECS primers were used to amplify specific sequences. The total protein of the transgenic line was extracted and incubated with anti-GFP antibodies (1:5000; Beijing) and HRP-conjugated IgG secondary antibodies (1:5000; Transgen, Beijing) to detect the GFP fusion protein.

\section{Y-ECS activity analysis}

The excised leaves ( $0.5 \mathrm{~g}$ fresh weight) were ground in a mortar to a fine powder with extraction buffer $(50 \mathrm{mM}$ Hepes, pH7.5, $5 \mathrm{mM} \mathrm{MgCl}_{2}, 100 \mathrm{mM} \mathrm{NaCl}$ and $10 \%$ glycerol) [53]. The enzymatic activities of $\gamma$-ECS were determined spectrophotometrically at $25^{\circ} \mathrm{C}$ by measuring the rate of ADP formation using a coupling assay of pyruvate kinase and lactate dehydrogenase [54]. The extraction buffer contained $50 \mathrm{mM}$ Tris, $\mathrm{pH} 8.0,500 \mathrm{mM} \mathrm{NaCl}$, $25 \mathrm{mM}$ imidazole, $5 \mathrm{mM} \mathrm{MgCl}_{2}, 10 \%(\mathrm{v} / \mathrm{v})$ glycerol and $1 \%(\mathrm{v} / \mathrm{v})$ Tween 20 . A common reaction mixture $(0.5 \mathrm{ml})$ was used for both proteins and contained $100 \mathrm{mM}$ Hepes (pH7.5), $150 \mathrm{mM} \mathrm{NaCl}, 10 \mathrm{mM} \mathrm{MgCl}_{2}, 2 \mathrm{mM}$ sodium phosphoenolpyruvate (PEP), $0.2 \mathrm{mM} \mathrm{NADH}, 5$ units of type III rabbit muscle pyruvate kinase and 10 units of type II rabbit muscle lactate dehydrogenase [54]. The decrease rate in $\mathrm{A}_{340} \mathrm{~nm}$ was tracked using a spectrophotometer (V-1100D, Mapada).

\section{Measurement of relative water content, leaf water loss, and MDA content}

The WT and overexpressing lines under drought for 7 days were sampled to detect relative water content (RWC), water loss, and MDA content. The RWC was determined as described previously [50]. The water loss determination was carried out according to [55]. MDA was measured by thiobarbituric acid reactive substances (TBARS) assay. Samples of $0.5 \mathrm{~g}$ leaves were ground in liquid $\mathrm{N}_{2}$ and then were added to $1.5 \mathrm{ml} 20 \%$ trichloroacetic acid (TCA). The homogenate was centrifuged at $3000 \mathrm{r} / \mathrm{min}$ for $10 \mathrm{~min}$. Then the supernatant was then added to $1.5 \mathrm{ml}$ of $0.5 \%$ thiobarbituric acid (TBA). The supernatant was heated to $100{ }^{\circ} \mathrm{C}$ for $10 \mathrm{~min}$. The supernatant of $2 \mathrm{ml}$ was sampled for measurement, and $0.5 \%$ TBA was used as a control. The absorbance of the supernatant was measured at 450,532, and $600 \mathrm{~nm}$. The difference was used to calculate the amount of MDA using an extinction coefficient of $6.22 \mathrm{~mm}^{-1} \mathrm{~cm}^{-1}$.

\section{Statistical analysis}

Data analysis was performed using SPSS 17 (SPSS Inc., Chicago, IL, USA). Data are presented as the mean \pm standard deviation. Student's t test and one-way analysis of variance (ANOVA) (LSD model) were used to test differences where it is appropriate. $P<0.05$ was considered a statistically significant difference for two-tailed tests. All figures were plotted in Origin 9.0 (Northampton, MA, USA). 


\begin{abstract}
Abbreviations
Y-ECS: Gamma-glutamylcysteine synthetase; Cky-ECS: Caragana korshinskii Y-ECS; ROS: Reactive oxygen species; GSH: Glutathione; GMC: Guard mother cells; bHLH: Basic helix-loop-helix; SPCH: SPEECHLESS; EPFs: EPIDERMAL PATTERNING FACTORS; ER: ERECTA; TMM: TOO MANY MOUTHS; AuX/IAA: Auxin/ indole-3-acetic acid; ARFs: Auxin response factors; PEG 6000: Polyethylene glycol-6000; RT-PCR: Reverse-transcription PCR; GH3: Gretchen Hagen3; LBD: Lateral organ boundaries; WT, ecotype Col0: Wild-type Arabidopsis thaliana; OE: Overexpressing; PBS, pH 6.8: Phosphate buffer; SEM6360LV: Scanning electron microscopy; EB: Ethidium bromide; NJ: Neighbor-joining; PEP: Phosphoenolpyruvate; RWC: Relative water content; FW: Weight; TW: Turgid weight; DW: Constant weight; TBARS: Thiobarbituric acid reactive substances; TCA: Trichloroacetic acid; TBA: Thiobarbituric acid; ANOVA: Analysis of variance; WT: Wild type; OE: Overexpression.
\end{abstract}

\section{Supplementary Information}

The online version contains supplementary material available at https://doi. org/10.1186/s12870-021-03226-9.

Additional file 1: Fig. S1. Cky-ECS Sequence in transcriptome data. Fig. S2. Cloning the Cky-ECS gene by PCR. Fig. S3. Detection of Arabidopsis transgenic lines overexpressing Cky-ECS. Schematic representation of constructs used for agroinfiltration (a). Screening Overexpressing plant from 1/2 MS medium with antibiotic (b). RT-PCR of amplification of Cky-ECS gene in Overexpressing Arabidopsis (c). The western blotting analysis in the transgenic lines (d). Fig. S4. Phenotype (a) and statistical analysis (b, c, and d) of leaf growth of transgenic lines and wild type on 1/2 MS medium. The data represented mean $\pm \mathrm{SD}(n \geq 3), \mathrm{WT}=$ wild type, OE $=$ overexpressing plants. ${ }^{*}$ indicates that compared with WT, $P<0.05$.

\section{Acknowledgments}

This work was supported by the National Natural Science Foundation of China (grant \#:31870586) and the Natural Science Basic Research Plan in Shaanxi Province of China (grant \#:2016JQ3006).

\section{Authors' contributions}

B Lu performed the experiment and drafted the manuscript; X Luo performed part of the SEM experiment and provided technical support; C Gong performed part of data analysis; J Bai conceived and supervised the study, and edited the manuscript; all authors have read and approved the final manuscript.

\section{Funding}

This work was supported by the National Natural Science Foundation of China (grant \#:31870586) and the Natural Science Basic Research Plan in Shaanxi Province of China (grant \#: 2016JQ3006).

\section{Availability of data and materials}

Sequence information was submitted to NCBI GenBank with the accession number $\mathrm{MH} 287046$.

\section{Declarations}

\section{Ethics approval and consent to participate}

The study material did not involve endangered or protective species and no specific permit is required for the sampling. We have followed current laws and ethical guidelines in China in the study.

\section{Consent for publication}

Not applicable.

\section{Competing interests}

The authors declare that they have no competing interests.

\section{Author details}

${ }^{1}$ College of Horticulture, Northwest A\&F University, Yangling 712100, Shaanxi, China. ${ }^{2}$ College of Life Sciences, Northwest A\&F University, Yangling 712100,
Shaanxi, China. ${ }^{3}$ School of Life Sciences, East China Normal University, Shanghai 200241, China.

Received: 12 March 2021 Accepted: 20 September 2021

Published online: 01 October 2021

\section{References}

1. Baldoni E, Genga A, Cominelli E. Plant MYB transcription factors: their role in drought response mechanisms. Int J Mol Sci. 2015;16(7):15811-51.

2. Yamauchi S, Mano S, Oikawa K, Hikino K, Teshima KM, Kimori Y, et al. Autophagy controls reactive oxygen species homeostasis in guard cells that is essential for stomatal opening. Proc Natl Acad Sci U S A. 2019;116(38):19187-92.

3. Rolli E, Marasco R, Vigani G, Ettoumi B, Mapelli F, Deangelis ML, et al. Improved plant resistance to drought is promoted by the root-associated microbiome as a water stress-dependent trait. Environ Microbiol. 2014;17(2):316-31.

4. Chen J, Nolan TM, Ye H, Zhang M, Tong H, Xin P, et al. Arabidopsis WRKY46, WRKY54, and WRKY70 transcription factors are involved in brassinosteroid-regulated plant growth and drought responses. Plant Cell. 2017;29(6):1425-39.

5. Basu S, Ramegowda V, Kumar A, Pereira A. Plant adaptation to drought stress. F1000Res. 2016;5:F1000 Faculty Rev-554.

6. Mhamdi A, Van Breusegem F. Reactive oxygen species in plant development. Development. 2018;145(15):dev164376.

7. Mittler R. Oxidative stress, antioxidants and stress tolerance. Trends Plant Sci. 2002;7(9):405-10.

8. Cruz de Carvalho MH. Drought stress and reactive oxygen species: production, scavenging and signaling. Plant Signal Behav. 2008;3(3):156-65.

9. Potters G, Jansen MAK, Horemans N, Guisez Y, Pasternak T. Dehydroascorbate and glutathione regulate the cellular development of Nicotiana tabacum L. SR-1 protoplasts. In Vitro Cell Dev Biol Plant. 2010;46(3):289-97.

10. Noctor G, Mhamdi A, Chaouch S, Han YI, Neukermans J, Marquez-Garcia $B$, et al. Glutathione in plants: an integrated overview. Plant Cell Environ. 2011;35(2):454-84.

11. Noctor G, Foyer CH. ASCORBATE AND GLUTATHIONE: keeping active oxygen under control. Annu Rev Plant Physiol Plant Mol Biol. 1998;49(1):249-79.

12. Hell R, Bergmann L. $\lambda$-Glutamylcysteine synthetase in higher plants: catalytic properties and subcellular localization. Planta. 1990;180(4):603-12.

13. Guo J, Dai X, Xu W, Ma M. Overexpressing GSH1 and AsPCS1 simultaneously increases the tolerance and accumulation of cadmium and arsenic in Arabidopsis thaliana. Chemosphere. 2008;72(7):1020-6.

14. Herschbach C, Rizzini L, Mult S, Hartmann T, Busch F, Peuke AD, et al. Overexpression of bacterial $\gamma$-glutamylcysteine synthetase (GSH1) in plastids affects photosynthesis, growth and sulphur metabolism in poplar (Populus tremulaxP. alba) dependent on the resulting $\mathrm{Y}$-EC and GSH levels. Plant Cell Environ. 2010;33(7):1138-51.

15. Creissen G, Firmin J, Fryer M, Kular B, Leyland N, Reynolds H, et al. Elevated glutathione biosynthetic capacity in the chloroplasts of transgenic tobacco plants paradoxically causes increased oxidative stress. Plant Cell. 1999;11(7):1277-92.

16. Samuilov S, Lang F, Djukic M, Djunisijevic-Bojovic D, Rennenberg $H$. Lead uptake increases drought tolerance of wild type and transgenic poplar (Populus tremula x P. alba) overexpressing gsh 1. Environ Pollut. 2016;216:773-85

17. Hatano-Iwasaki A, Ogawa K. Overexpression of GSH1 gene mimics transcriptional response to low temperature during seed vernalization treatment of Arabidopsis. Plant Cell Physiol. 2012;53(7):1195-203.

18. Hetherington AM, Woodward Fl. The role of stomata in sensing and driving environmental change. Nature. 2003;424(6951):901-8.

19. Sierla M, Rahikainen M, Salojärvi J, Kangasjärvi J, Kangasjärvi S. Apoplastic and chloroplastic redox signaling networks in plant stress responses. Antioxid Redox Signal. 2013;18(16):2220-39.

20. Gudesblat GE, Schneider-Pizoń J, Betti C, Mayerhofer J, Vanhoutte I, van Dongen W, et al. SPEECHLESS integrates brassinosteroid and stomata signalling pathways. Nat Cell Biol. 2012;14(5):548-54. 
21. Ohashi-Ito K, Bergmann DC. Arabidopsis FAMA controls the final proliferation/differentiation switch during stomatal development. Plant Cell. 2006;18(10):2493-505.

22. Pillitteri LJ, Sloan DB, Bogenschutz NL, Torii KU. Termination of asymmetric cell division and differentiation of stomata. Nature. 2006;445(7127):501-5.

23. Bergmann DC. Stomatal development and pattern controlled by a MAPKK kinase. Science. 2004;304(5676):1494-7.

24. Lampard GR, Lukowitz W, Ellis BE, Bergmann DC. Novel and expanded roles for MAPK signaling in Arabidopsis stomatal cell fate revealed by cell type-specific manipulations. Plant Cell. 2009;21(11):3506-17.

25. Hara K, Kajita R, Torii KU, Bergmann DC, Kakimoto T. The secretory peptide gene EPF1 enforces the stomatal one-cell-spacing rule. Genes Dev. 2007:21(14):1720-5.

26. Hunt L, Gray JE. The signaling peptide EPF2 controls asymmetric cell divisions during stomatal development. Curr Biol. 2009;19(10):864-9.

27. Lee JS, Hnilova M, Maes M, Lin Y-CL, Putarjunan A, Han S-K, et al. Competitive binding of antagonistic peptides fine-tunes stomatal patterning. Nature. 2015;522(7557):439-43.

28. Yang $M$, Sack FD. The too many mouths and four lips mutations affect stomatal production in Arabidopsis. Plant Cell. 1995;7(12):2227-39.

29. Geisler M, Nadeau J, Sack FD. Oriented asymmetric divisions that generate the stomatal spacing pattern in Arabidopsis are disrupted by the too many mouths mutation. Plant Cell. 2000;12(11):2075.

30. Shen $H$, Zhong $X$, Zhao F, Wang Y, Yan B, Li Q, et al. Overexpression of receptor-like kinase ERECTA improves thermotolerance in rice and tomato. Nat Biotechnol. 2015;33(9):996-1003.

31. Rychel AL, Peterson KM, Torii KU. Plant twitter: ligands under 140 amino acids enforcing stomatal patterning. J Plant Res. 2010;123(3):275-80.

32. Sugano SS, Shimada T, Imai Y, Okawa K, Tamai A, Mori M, et al. Stomagen positively regulates stomatal density in Arabidopsis. Nature. 2009;463(7278):241-4

33. Gray WM, Kepinski S, Rouse D, Leyser O, Estelle M. Auxin regulates SCFTIR1-dependent degradation of AUX/IAA proteins. Nature. 2001;414(6861):271-6.

34. Chapman EJ, Estelle M. Mechanism of auxin-regulated gene expression in plants. Annu Rev Genet. 2009;43(1):265-85.

35. Bouzroud S, Gasparini K, Hu G, Barbosa MAM, Rosa BL, Fahr M, et al. Down regulation and loss of auxin response factor 4 function using CRISPR/ Cas 9 alters plant growth, stomatal function and improves tomato tolerance to salinity and osmotic stress. Genes (Basel). 2020;11(3):272.

36. Zhang J-Y, He S-B, Li L, Yang H-Q. Auxin inhibits stomatal development through MONOPTEROS repression of a mobile peptide gene STOMAGEN in mesophyll. Proc Natl Acad Sci U S A. 2014;111(29):E3015-E23.

37. Jahan MS, Ogawa KI, Nakamura Y, Shimoishi Y, Mori IC, Murata Y. Deficient glutathione in guard cells facilitates abscisic acid-induced stomatal closure but does not affect light-induced stomatal opening. Biosci Biotechnol Biochem. 2008;72(10):2795-8.

38. Bai J, Kang T, Wu H, Lu B, Long X, Luo X, et al. Relative contribution of photorespiration and antioxidative mechanisms in Caragana korshinskii under drought conditions across the Loess Plateau. Funct Plant Biol. 2017:44(11):1111.

39. Wang S, Bai Y, Shen C, Wu Y, Zhang S, Jiang D, et al. Auxin-related gene families in abiotic stress response in Sorghum bicolor. Funct Integr Genomics. 2010;10(4):533-46.
40. Jung H, Lee D-K, Choi YD, Kim J-K. OsIAA6, a member of the rice Aux/IAA gene family, is involved in drought tolerance and tiller outgrowth. Plant Sci. 2015;236:304-12

41. Liu T, Ohashi-Ito K, Bergmann DC. Orthologs of Arabidopsis thaliana stomatal bHLH genes and regulation of stomatal development in grasses. Development. 2009;136(13):2265-76.

42. Jewaria PK, Hara T, Tanaka H, Kondo T, Betsuyaku S, Sawa S, et al. Differential effects of the peptides Stomagen, EPF1 and EPF2 on activation of MAP kinase MPK6 and the SPCH protein level. Plant Cell Physiol. 2013;54(8):1253-62.

43. Hronková M, Wiesnerová D, Šimková M, Skůpa P, Dewitte W, Vráblová $M$, et al. Light-induced STOMAGEN-mediated stomatal development in Arabidopsisleaves. J Exp Bot. 2015;66(15):4621-30.

44. Lampard GR, Bergmann DC. A shout-out to stomatal development: how the bHLH proteins SPEECHLESS, MUTE and FAMA regulate cell division and cell fate. Plant Signal Behav. 2007;2(4):290-2.

45. Kim T-W, Michniewicz M, Bergmann DC, Wang Z-Y. Brassinosteroid regulates stomatal development by GSK3-mediated inhibition of a MAPK pathway. Nature. 2012;482(7385):419-22.

46. McSteen P. Auxin and monocot development. Cold Spring Harb Perspect Biol. 2010;2(3):a001479.

47. Balcerowicz M, Ranjan A, Rupprecht L, Fiene G, Hoecker U. Auxin represses stomatal development in dark-grown seedlings via Aux/IAA proteins. Development. 2014;141(16):3165-76.

48. Song Y, Wang L, Xiong L. Comprehensive expression profiling analysis of OsIAA gene family in developmental processes and in response to phytohormone and stress treatments. Planta. 2008;229(3):577-91.

49. Smart RE. Rapid estimates of relative water content. Plant Physiol. 1974;53(2):258-60.

50. Wang J, Ding B, Guo Y, Li M, Chen S, Huang G, et al. Overexpression of a wheat phospholipase D gene, TaPLDa, enhances tolerance to drought and osmotic stress in Arabidopsis thaliana. Planta. 2014;240(1):103-15.

51. Sharma P, Jha AB, Dubey RS, Pessarakli M. Reactive oxygen species, oxidative damage, and antioxidative defense mechanism in plants under stressful conditions. J Bot. 2012;2012:1-26.

52. Clough SJ, Bent AF. Floral dip: a simplified method forAgrobacterium-mediated transformation of Arabidopsis thaliana. Plant J. 1998;16(6):735-43.

53. Musgrave William B, Yi H, Kline D, Cameron Jeffrey C, Wignes J, Dey S, et al. Probing the origins of glutathione biosynthesis through biochemical analysis of glutamate-cysteine ligase and glutathione synthetase from a model photosynthetic prokaryote. Biochem J. 2013;450(1):63-72.

54. Jez JM, Cahoon RE, Chen S. Arabidopsis thaliana glutamate-cysteine ligase. J Biol Chem. 2004;279(32):33463-70.

55. Liang Y-K, Xie X, Lindsay SE, Wang YB, Masle J, Williamson L, et al. Cell wall composition contributes to the control of transpiration efficiency in Arabidopsis thaliana. Plant J. 2010;64(4):679-86.

\section{Publisher's Note}

Springer Nature remains neutral with regard to jurisdictional claims in published maps and institutional affiliations. 